In order to structure the meeting, the Planning Committee is requiring a not-more-thanone-page description of the proposal, stating (1) the name and address of the person (or persons) presenting the idea, (2) the problem to be solved by the proposal, and (3) the general plan of procedure. Anyone is invited to present a proposal. The only restriction is that it must lie within the division's areas of responsibility; acquisitions, cataloging, classification, serials, reproduction, and resources.

Projects will be presented and discussed at a meeting of the Planning Committee during the ALA Conference in Kansas City. The meeting is scheduled for Wednesday, June 26, 1968 at 4:30 p.m. The place will be listed in the Conference Program and will also be reported to those sending in proposals. Available at the meeting for consultation will be members of the Policy and Research Committees of the RTSD sections-Acquisitions, Cataloging and Classification, Serials, and Reproduction of Library Materials-as well as a representative of the Resources Committee.

When a proposal is accepted, action to set it in motion will be taken. If it falls within a section's responsibilities, it will be referred to the appropriate Policy and Research Committee. It might go to one of the divisional committees. It might warrant a recommendation to the RTSD Board that an ad hoc committee be created. In every case, the intention is that the person making the proposal be a central figure in the implementation of his idea.

To be included in the Kansas City meeting, the proposal must be received by May 15, 1968. Descriptive sheets should be addressed to: Helen M. Welch, Chairman of the RTSD Planning Committee, University of Illinois Library, Urbana, Illinois 61801.

\section{INFORMATION NEEDED}

ACRL has been requested to present a program on "Educational Potential for LiBRARIES IN Living UNITs" at the Annual Conference of the National Association of Students Personnel Administrators, on April 2.

We would be grateful if information and policy statements regarding practices and programs in Academic Libraries would be sent to: Edward B. Stanford, Director of Libraries, University of Minnesota, Minneapolis, Minnesota 55455 .

The Guidelines for Library Service to Extension Students were officially endorsed by the National University Extension Association at its 1967 Annual Meeting and reprinted in the NUEA Spectator, October-November 1967.

\section{Your Certified}

\section{Library Binder} belongs on

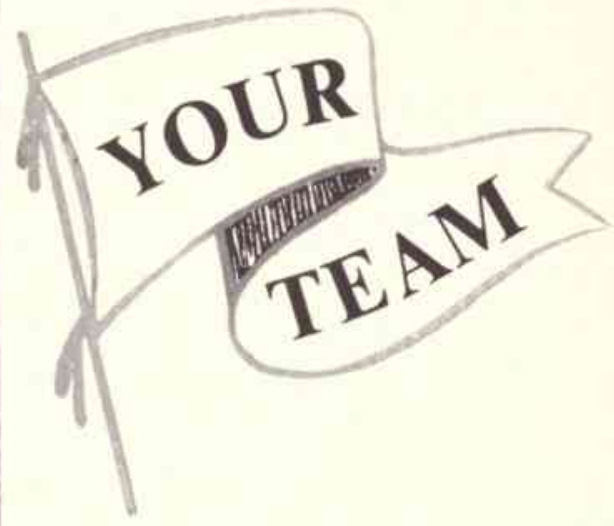

Only one man can help you get the most from your books. He is your

Certified Library Binder - the man who rebinds your worn books according to CERTIFIED STANDARDS so that they will multiply your circulation five times at less than half the cost. He is the man who can beautify your library with quality - who can inspire good reading by making books attractive too whether books have been prebound or rebound.

\section{THIS SEAL GUARANTEES PERFORMANCE}

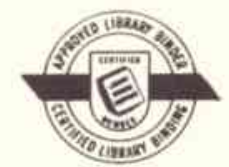

It is the stamp of approval given only to CERTIFIED LIBRARY BINDERS which is your assurance that your books have been bound according to the standards of the Library Binding Institute.

Without this seal, you have no assurance that your books have been truly library bound.

\section{Be well informed, write today for free literature.}

There is no obligation.

\section{LIBRARY BINDING INSTITUTE}

160 State Street

Boston, Massachusetts 02109 


\section{When 250,000 scientific}

\section{and technological articles}

\section{are indexed each year--and}

each is indexed to a depth of approximately 35 entries -that's subject indexing at its finest. And it's available now in

\section{the PERMUTERM" SUBJECT INDEX to Science and Technology.}

Librarians asked for it. And ISI produced it-the PERMUTERM SUBJECT INDEX 1966 to Science and Technology. PSI"quickly locates articles for you on the specific or generic subjects you are interested in, through this daring new concept in subject indexing. Using the computer, like a computer was meant to be used, ISI's exclusive Permuterm programs index the average article to a depth of approximately 35 entries. Sample formats and details are available at no obligation.

Order the PERMUTERM SUBJECT INDEX. You and your library clientele will be glad you did. Write dept. 12-14

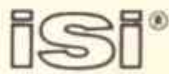

